ДОСВІД ЗАСТОСУВАННЯ СУЧАСНИХ ОНЛАЙН-ПЛАТФОРМ

У ПРОФЕСІЙНІЙ ПІДГОТОВЦІ МАЙБУТНІХ ІНЖЕНЕРІВ ПРИ ВИВЧЕННІ АНГЛІЙСЬКОЇ МОВИ

\title{
EXPERIENCE OF APPLICATION OF MODERN ONLINE PLATFORMS IN THE PROFESSIONAL TRAINING OF FUTURE ENGINEERS IN THE STUDY OF ENGLISH
}

УДК 372.881.111.1

DOI https://doi.org/10.32843/2663-

$6085 / 2021 / 39.34$

\section{Лисенко Т.П.,}

старший викладач кафредри англійської мови технічного спрямування № 1

Національного технічного університету України «Київський політехнічний інститут імені Ігоря Сікорського»

\section{Лісецький К.А.,}

старший викладач кафредри англійської мови технічного спрямування № 1 Національного технічного університету України «Київський політехнічний інститут імені Ігоря Сікорського»

\section{Мойсеєнко С.М.,}

канд. фрілол. наук,

доцент кафедри англійської мови технічного спрямування № 1

Національного технічного університету України «Київський політехнічний інститут імені Ігоря Сікорського»
Стаття присвячена інструментам використання сучасних онлайн-платформ (LMS Moodle, Zoom) у підготовці студентів інженерних напрямів для навчання іноземних мов (на прикладі англійської мови). Актуальність дослідження пояснюється інтернаціоналізацією вищої освіти, яка диктує потребу у кваліфрікованих інженерах зі знанням англійської мови на ринку праці. Метою наукової статmі виступає розкриття практичного досвіду застосування сучасних онлайн-платсрорм у просресійній підготовці майбутніх інженерів під час вивчення англійської мови. Описано основні особливості системи LMS Moodle, виявлено основні умови організації навчального процесу, а також запропоновано алгоритм роботи на платформі LMS Moodle із метою профорієнтації студентів - майбутніх інженерів. У зв'язку із цим упровадження нових методів і прийомів, здатних прискорити та полегшити процес навчання фрахівців у даній сорері, на основі нових інноваційних інфрормаційних технологій і методик стало невід'ємною частиною для успішного розвитку міжкультурної профеесійної компетенції у студентів. Робота з онлайн-сервісами $\epsilon$ більш ефекктивною формою навчальної діяльності, яка не тільки підвищує увагу, а й допомагає поліпшити практично всі навички, оскільки в разі навчання з використанням онлайн-сервісів матеріали дуже різноманітні. Пропонований курс англійської мови для студентів-інженерів передбачає такі результати навчання: опанування різних стратегій читання (навчальні, ознайомлювальні, пошукові й оглядові) на матеріалі автентичних загальнонаукових та наукових текстів за фрахом різного об'єму; розвиток навичок сприйняття усного мовлення за загальнонауковою $і$ вузькоспеціальною тематиками на матеріалі лекцій фрахівців - носіїв мови, знайомство студентів з узагальненими алгоритмами профресійно-мовної поведінки в ситуаціях іншомовного спілкування; фрормування вмінь публічного мовлення у форматі наукової презентації, доповіді на наукових конореренціях; розвиток навичок іншомовного спілкування з наукових тем (проведення дискусій у групі з актуальних наукових тем і виступ із презентаціями); розвиток навичок $i$ вмінь продуктивного писемного мовлення, зокрема i через реферативний виклад змісту наукових статей англійською мовою, анотування наукових статей. Ключові слова: онлайн-платсорми, SMART-mехнології, LMS Moodle, онлайн- сервіси, технології навчання іноземних мов, інсрормаційні технології, англійська мова.

The article is devoted to the tools of using modern online platforms (LMS Moodle, Zoom) in the preparation of engineering students for learning foreign languages (on the example of English). The relevance of the study is explained by the internationalization of higher education, which dictates the need for qualified engineers with knowledge of English in the labor market. The purpose of the scientific article is to reveal the practical experience of using modern online platforms in the training of future engineers in the study of English. The main features of the LMS Moodle system are described, the basic conditions of the organization of educational process are revealed, and also the algorithm of work on the LMS Moodle platform for the purpose of vocational guidance of students - future engineers is offered. Therefore, the introduction of new methods and techniques that can accelerate and facilitate the training of professionals in this field on the basis of new innovative information technologies and techniques has become an integral part for the successful development of intercultural professional competence in students. Working with online services is a more effective form of learning activities, which not only increases attention, but also helps to improve almost all skills, as when learning using online services, the materials are very diverse. The offered English language course for engineering students provides the following learning outcomes: mastering various reading strategies (educational, introductory, search and review) on the material of authentic general scientific and scientific texts in the field of different volumes; development of skills of perception of oral speech on general scientific and narrowly special subjects on a material of lectures of experts-native speakers and acquaintance of students with the generalized algorithms of professional-language behavior in situations of foreign language communication; formation of public speaking skills in the format of a scientific presentation, reports at scientific conferences; development of skills of foreign language communication on scientific topics (conducting group discussions on topical scientific topics and giving presentations); development of skills and abilities of productive written speech, including through an abstract presentation of the content of scientific articles in English, annotation of scientific articles. Key words: online platforms, SMARTtechnologies, LMS Moodle, online services, foreign language learning technologies, information technologies, English language.
Постановка проблеми в загальному вигляді. У світовому товаристві розвиваються процеси глобальної інфрорматизації всіх сфрер суспільного життя. Варто також зауважити, що в усіх розвинених країнах відбуваються інтен- сивні процеси інформатизації освіти, розробляються шляхи підвищення результативності загальної освіти, вкладаються великі кошти в розроблення і впровадження нових інформаційних технологій [1]. 
Інноваційні підходи до організації та проведення навчальних занять 3 іноземної мови, зокрема і вивчення англійської мови, засновані на використанні інорормаційних і комунікаційних технологій, які передбачають перебудову змісту й організаційно-методичних фрорм навчання, розроблення сучасних засобів інфрормаційно-технологічної підтримки і розвитку навчального процесу, зокрема й засобів роботи із цифровими навчальними матеріалами, організацію роботи в режимі онлайн.

Аналіз останніх досліджень і публікацій. Над розкриттям проблем підготовки студентів майбутніх інженерів під час вивчення іноземної мови працювали та продовжують працювати М.С. Ляшенко [2], Г.Е. Міхненко [3], А.С. Фоміна [4] й інші [5-6].

Виділення не вирішених раніше частин загальної проблеми. Проте, як показують огляд і аналіз джерел з окресленої проблематики, не розкритими є питання практичного досвіду щодо застосування сучасних онлайн-платорорм у професійній підготовці майбутніх інженерів під час вивчення англійської мови.

Метою наукової статті виступає розкриття практичного досвіду застосування сучасних онлайнплатформ у професійній підготовці майбутніх інженерів під час вивчення англійської мови.

Виклад основного матеріалу. 3 огляду на умови комп'ютеризації та глобалізації освіти постає питання, чи потрібно впроваджувати інтернет-технології й онлайн-сервіси в освітній процес. Освіта являє собою багатофракторну модель, у якій наука може сприяти високій швидкості просування до мети зі створення науково-освітнього корпоративного товариства студентів, профресорсько-викладацького складу, випускників університету. Одне 3 основних завдань закладу вищої освіти (далі 3ВО) полягає в забезпеченні високого рівня підготовки фрахівців і фрормуванні особистості, готової до ухвалення соціально-відповідальних рішень в умовах відкритого суспільства, до інноваційного кар'єрного просування і професійного зростання.

Головною метою навчання іноземних мов $€$ розвиток комунікативної компетенції, що, своєю чергою, передбачає формування і розвиток комунікативних умінь студентів у розумінні усного мовлення на слух, говоріння, читання та писемного мовлення іноземною мовою. Отже, опираючись на зазначене вище, доцільно зауважити, що розвиток умінь у студентів під час вивчення іноземної мови, англійської мови також, здебільшого можливий завдяки застосуванню в навчальному процесі сучасних онлайн-платформ. Так, особливостями застосування онлайн-платформ у вивченні іноземної мови, зокрема англійської, $€$ [3]: 1) велика аудиторія для загального заняття, можливість ділитися на групи, пари; 2) можливість коментувати, ставити запитання; 3) мультиканальна особливість, орієнтована на всі види мовленнєвої діяльності, тобто на письмо, говоріння, аудіювання, читання; 4) використання, крім традиційних методів, інтерактивних методів навчання; 5) можливість використання електронних навчальних матеріалів, інтерактивної дошки; 6) фуункція контролю успішності студентів і можливість оцінювання безпосередньо на заняттях.

Останніми роками найбільш потрібною під час навчання іноземної мови студентів інженерних спеціальностей стає технологія змішаного навчання, тобто blended learning. Дана технологія передбачає комбінування різних способів подачі навчального матеріалу (очне, електронне та самостійне навчання) із застосуванням методики управління знаннями [4].

У контексті зазначеного постає необхідність у пошуку ефективних методів, підходів і технологій для організації навчання іноземної мови в умовах реалізації нових освітніх стандартів. Найбільш перспективним було обрано модульне об'єктно орієнтоване динамічне навчальне середовище (Moodle), що дозволяє розробляти, структурувати і розміщувати електронні ресурси для організації самостійної роботи студентів під час підготовки до заліків та іспитів. За допомогою даної системи можна завантажувати на сервер фрайли, що містять навчальні та навчально-методичні посібники (зокрема, мультимедійні), книги, презентації, тренувальні та тестові завдання. Також $є$ можливість організувати гіперпосилання на електронні ресурси, що знаходяться у вільному доступі в мережі Інтернет [2].

Досвід роботи в немовному ЗВО, зокрема й у тому, що здійснює професійну підготовку майбутніх інженерів, показує, що неможливо уявити процес навчання англійської мови без використання цифррових технологій, мережі Інтернет, телекомунікаційних та дистанційних технологій. За допомогою новітніх технологічних досягнень використання методу проєктів, методу case-study, арт-технологій і багатьох інших отримує нові ефективні можливості для своєї реалізації.

Доцільно зауважити, що використання SMARTтехнологіїздатнезабезпечитидоситьвисокийрівень компетентності студентів шляхом розвитку практико-орієнтованих курсів у контексті проведення майстер-класів, тренінгів, а також забезпечення взаємодії з потенційними роботодавцями з обраних тем навчання, створення професійних товариств.

Акцентуючи увагу на підвищенні якості освіти в контексті використання SMART-технологій, не треба забувати і про можливість постійного підвищення рівня кваліфрікації профресорсько-викладацького складу, тому що рівень якості педагогічних кадрів залишається одним із найважливіших компонентів освітньої системи, від якої залежить реалізація всього освітнього процесу. 
Так, в організації самостійної роботи студентів як майбутніх інженерів значну допомогу надають можливості такого додатка, як WhatsApp. За його допомогою видаються домашні завдання у вигляді аудіо-, відеозапису, фрото або тексту. Для викладача це зручний спосіб перевірки завдань, для студента - це спосіб самоконтролю, пов'язаний із практикою усного мовлення, аудіювання тощо [6].

Важливим елементом вивчення англійської мови, особливо мови професійного спілкування, є проєктна діяльність (або метод проєктів). Складно уявити підготовку і презентацію проєктів без використання інтернет-ресурсів, мультимедійних технологій тощо. Неможливо не відзначити висхідну роль дистанційних технологій у навчанні. За допомогою таких платорорм, як Zoom або Teams, стали легкодоступними організація та проведення відеоконореренцій, вебінарів, спілкування 3 носіями мови за кордоном.

Коли говоримо про можливості інтернету в навчанні іноземної, зокрема й англійської, мови, можна виділити ті, які є найбільш ефективними: 1) електронне листування (електронна пошта, соцмережі) з однолітками - носіями мови сприяє знайомству із сучасною живою мовою, діалогами, актуальною інформацією, що дає можливість учитися, знайомитися з іншою культурою, пріоритетом $€$ отримання знань із «перших рук»); 2) участь у міжнародних телекомунікаційних проєктах (підвищення рівня мовних навичок, розвиток кругозору, отримання спеціальних знань, які можна використовувати для реалізації конкретних навичок); 3) участь у текстових і голосових чатах; 4) участь у телекомунікаційних олімпіадах, тестах, конкурсах (об'єктивна оцінка знань, самоствердження, підготовка до іспитів, участь у різних видах конкурсів і олімпіад; у роботі такого роду спостерігається відсутність негативного психологічного моменту в більшості студентів, почуття страху, яке часто виникає в реальних ситуаціях); 5) можливість безкоштовно опублікувати результати творчих робіт (підвищення мотивації, можливість самоствердження); 6) для викладачів пропонується велика кількість мовного і закордонного матеріалу, докладний опис новітніх технологій викладання, можливість постійно підвищувати рівень своїх мовних навичок, звертатися до авторів автентичних навчальних комплексів, обмін досвідом із зарубіжними колегами [6].

3 метою вибору LMS Moodle, оптимальної для розроблення та впровадження онлайн-компоненти платорорми «Англійська мова для студентів інженерних спеціальностей» був проведений порівняльний аналіз технічних і педагогічних можливостей деяких із них відповідно до обраних вимог, а саме:

1. Для користувачів (бакалаври / спеціалісти): 1.1. Легкість у роботі 3 контентом, оптиміза- ція навчального часу; 1.2. Наявність дружнього інтерфейсу; 1.3. Постійне оновлення контенту; 1.4. Інфрормація доступна всім учасникам групи в будь-який момент часу з будь-якої точки перебування користувача; 1.5. Активна комунікація у групі; 1.6. Спільна робота над текстом або проєктом / спільне створення і редагування контенту; 1.7. Посилення аудіовізуального фрормату передачі даних; 1.8. Самостворення і самоспоживання інорормації; 1.9. Індивідуалізація і диференціації процесу навчання; 1.10. Забезпечення зворотного зв'язку з коучем / викладачем.

2. Для розробників / викладачів: 2.1. Постійне підключення до мережі Інтернет; 2.2. Зручність у завантаженні змістовної навчальної інорормації та підтримки чи оновлення курсу; 2.3. Упровадження аудіо-, відео- й ілюстративних даних; 2.4. Оперативне поширення інорормації серед користувачів; 2.5. Спільне з користувачами редагування контенту; 2.6. Створення бази для аналізу діяльності користувачів курсу, інтерпретації та подання зібраних даних, яка включає: а) академічні результати (виконання завдань, успішність проходження тестів); б) специоріку взаємодії користувачів курсу всередині групи; в) персональну інформацію про користувачів (профріль); 2.7. Зручність обробки й управління даними; 2.8. Контроль індивідуальної роботи користувача; 2.9. Дистанційне керування процесом навчання.

Виконаний аналіз підтвердив, що велика гнучкість і доступність використання електронної платорорми LMS Moodle сприяють успішному досягненню мети викладача англійської мови, яка полягає у формуванні не тільки комунікативної, а й профресійної компетенцій [2].

Розміщення всього навчального матеріалу на єдиній платорормі сприяє не тільки швидкому розміщенню і наданню навчального контенту студенту, його можливому багаторазовому використанню, але також плануванню, проведенню, управлінню всіма навчальними заходами під час реалізації програми.

Така модель навчання 3 використанням електронного освітнього курсу у студентів інженерних спеціальностей робить процес навчання іноземної мови гнучким, а викладача - вільним у виборі траєкторії навчання, у визначенні послідовності, логіки викладу, дає можливість змінювати темп навчання, навчальні техніки та підходи, аналізувати сполучуваність очної та дистанційної фоом роботи, чергувати тематичні блоки курсу. Навіть більше, використання професійно орієнтованої лексики і граматики допомагає успішному розвитку міжкультурної професійної комунікативної компетенції.

Висновки. Отже, пропонований курс англійської мови для студентів - майбутніх інженерів передбачає такі результати навчання: опанування різних стратегій читання (навчальні, озна- 
йомлювальні, пошукові й оглядові) на матеріалі автентичних загальнонаукових та наукових текстів за фрахом різного об'єму; розвиток навичок сприйняття усного мовлення із загальнонаукової і вузькоспеціальної тематик на матеріалі лекцій фрахівців - носіїв мови, знайомство студентів 3 узагальненими алгоритмами професійно-мовної поведінки в ситуаціях іншомовного спілкування; фрормування вмінь публічного мовлення у фрорматі наукової презентації, доповіді на наукових конфреренціях; розвиток навичок іншомовного спілкування 3 наукових тем (проведення дискусій у групі з актуальних наукових тем і виступ із презентаціями); розвиток навичок і вмінь продуктивного писемного мовлення, зокрема і через реферативний виклад змісту наукових статей англійською мовою, анотування наукових статей.

\section{БІБЛІОГРАФІЧНИЙ СПИСОК:}

1. Воног В.В., Жавнер Т.В., Кокорина С.В. Применение электронной платфрормы для успешного развития коммуникативной компетенции у студентов технических специальностей, изучающих иностранный язык в рамках образовательных программ совре- менного вуза. В мире научных открытий. 2013. № 11.1. С. 278-290.

2. Ляшенко М.С., Минеева О.А. Исследование эфффективности ресурсов Moodle для организации самостоятельной работы студентов в контексте изучения иностранного языка. Азимут научных исследований: педагогика и психология. 2020. Т. 9. № 2 (31). C. 162-166.

3. Міхненко Г.Е. Мультимедійний дистанційний курс «Англійська мова для майбутніх інженерів» для студентів 3-4 курсів технічних фракультетів НТУУ «КП|»: навчально-методична праця (Сертифрікат № 4248 УIITO HТУУ «KП|»). 2014. URL: http://moodle. ipo.kpi.ua/moodle/course/view/php?id=635.

4. Fomina A.S. Blended learning in the electronic distribution of the University. Scientific notes. 2014. Vol. 34. P. 82-88.

5. Hauck M., Stickler U. What does it take to teach online? CALICO Journal, Special Issue: What does it take to teach online? Towards a Pedagogy for Online Language Teaching and Learning. Equinox Publishing Ltd., 2006. Vol. 23. № 3. P. 463-475.

6. Watson J. Blended learning: The convergence of online and face-to-face education. Vienna : North American Council for Online Learning, 2008. 16 p. 